\title{
ECLETICA
}

www.scielo.br/eq

www.ecletica.iq.unesp.br

Volume 33, número 1, 2008

\section{Thermal decomposition of solid state compounds of lanthanide and yttrium benzoates in $\mathrm{CO}_{2}$ atmosphere}

\author{
J. R. Locatelli, A. B. Siqueira ${ }^{2}$, C. T. Carvalho ${ }^{2}$, M. Ionashiro ${ }^{2 *}$ \\ ${ }^{1}$ Academia da Força Aérea, AFA. Estrada de Aguaí; s/n, CEP 13630-000 Pirassununga, SP, Brazil. \\ ${ }^{2}$ Instituto de Química, UNESP, C. P. 355, CEP 14801 - 970 Araraquara, SP, Brazil \\ *massaoi@yahoo.com.br
}

\begin{abstract}
Solid-state Ln-Bz compounds, where Ln stands for trivalent lanthanides and $\mathrm{Bz}$ is benzoate have been synthesized. Simultaneous thermogravimetric and differential thermal analysis in a $\mathrm{CO}_{2}$ atmosphere were used to study the thermal decomposition of these compounds.
\end{abstract}

Keywords: lanthanides; benzoate; thermal decomposition; $\mathrm{CO}_{2}$ atmosphere.

\section{Introduction}

Benzoic acid and some of its derivatives are used as conservant, catalyst polymers precursors, in pharmaceutical industries, etc. A survey of literature shows that the complexes of rare earth elements with benzoic acid and some of their derivatives have been investigated in aqueous solutions [1-5] and in solid state [6-25].

In the present study, as an extension of the work of ref. 25, benzoates of trivalent lanthanides and yttrium (III) were investigated by using simultaneous thermogravimetry and differential thermal analysis (TG-DTA) in a $\mathrm{CO}_{2}$ atmosphere. The results of this study are discussed in connection with those found for previously study involving these compounds in an air atmosphere.

\section{Experimental}

The preparation of the solid state compounds of trivalent lanthanides and yttrium (III) with Bz, as well as, the determination of hydration water, metal- lic ions and ligand contents, the same procedure were used as previously described in Ref. 25.

The Simultaneous TG-DTA curves were obtained with thermal analysis system model SDT 2960 from TA Instruments. The purge gas was a $\mathrm{CO}_{2}$ with flow of $100 \mathrm{~mL} \mathrm{~min}^{-1}$. A heating rate of $20{ }^{\circ} \mathrm{C} \mathrm{min}^{-1}$ was adopted with samples weighing about $7 \mathrm{mg}$. Alumina crucibles were used for TG-DTA.

\section{Results and Discussion}

The analytical and thermoanalytical (TG) data were obtained in air atmosphere, Table 1 Ref. 25. These results establish the stoichiometry of these compounds, which are in agreement with the $\mathrm{Ln}(\mathrm{Bz})_{3} \cdot \mathrm{nH}_{2} \mathrm{O}$ general formula, where $\mathrm{Ln}$ represents trivalent lanthanides or yttrium, $\mathrm{Bz}$ is benzoate and $\mathrm{n}=2.5(\mathrm{Nd}), 2(\mathrm{La}, \mathrm{Ce}, \mathrm{Pr}, \mathrm{Sm}), 1.5$ (Eu, Gd), 1(Tb), 0.5 (Dy) and 0 (Ho to Lu and Y).

The simultaneous TG and DTA curves of the compounds are shown in Fig. 1. These curves exhibit mass loss in steps and endothermic peaks 

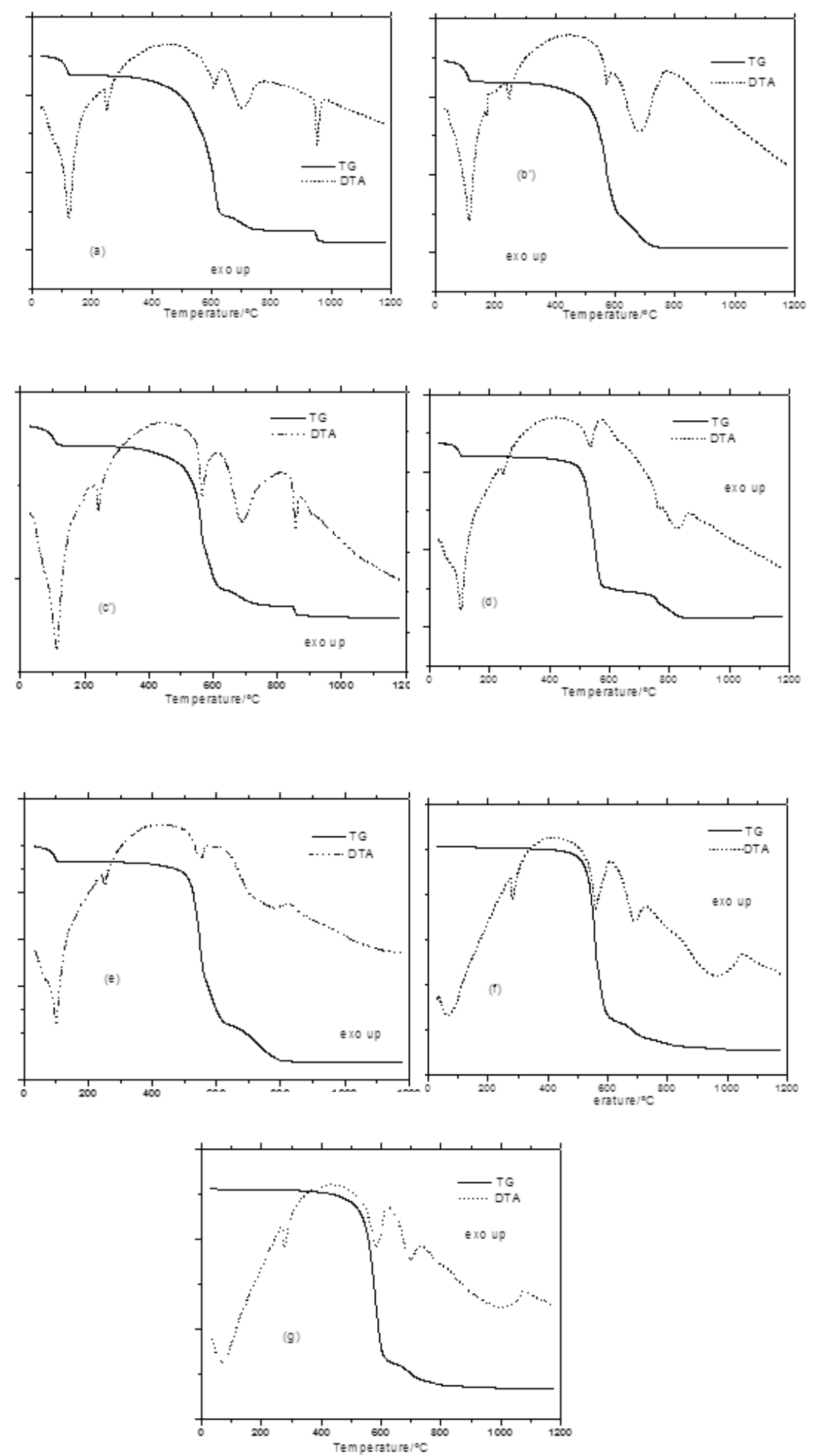

Figure 1. TG-DTA curves of the compounds: (a) $\mathrm{La}(\mathrm{L})_{3} \cdot 2 \mathrm{H}_{2} \mathrm{O}(\mathrm{m}=7.014 \mathrm{mg}),(\mathrm{b}) \mathrm{Ce}(\mathrm{L})_{3} \cdot 2 \mathrm{H}_{2} \mathrm{O}(\mathrm{m}=6.937 \mathrm{mg})$, (c) $\operatorname{Pr}(\mathrm{L})_{3} \cdot 2 \mathrm{H}_{2} \mathrm{O}(\mathrm{m}=7.156 \mathrm{mg})$, (d) $\mathrm{Eu}(\mathrm{L})_{3} \cdot 1.5 \mathrm{H}_{2} \mathrm{O}(\mathrm{m}=6.806 \mathrm{mg}),(\mathrm{e}) \mathrm{Gd}(\mathrm{L})_{3} \cdot 1.5 \mathrm{H}_{2} \mathrm{O}(\mathrm{m}=7.022 \mathrm{mg}),(\mathrm{f})$ $\mathrm{Ho}(\mathrm{L})_{3}(\mathrm{~m}=7.062 \mathrm{mg}),(\mathrm{g}) \mathrm{Yb}(\mathrm{L})_{3}(\mathrm{~m}=7.108 \mathrm{mg})$. L= benzoate. 
corresponding to these losses or due to physical phenomenon, Table 2.

For the lanthanum to dysprosium compounds, the first mass loss (range: $130-90^{\circ} \mathrm{C}$ ), associated to endothermic peaks at $120-80{ }^{\circ} \mathrm{C}$, is ascribed to the dehydration, which occurs in a single step. No influence of the atmosphere $\left(\mathrm{CO}_{2}\right.$ or air) was observed in the dehydration process of these compounds.

Once dehydrated, the anhydrous compounds are stable up to $350{ }^{\circ} \mathrm{C}$ (La to $\mathrm{Sm}$ ), 375 ${ }^{\circ} \mathrm{C}(\mathrm{Eu}), 385^{\circ} \mathrm{C}(\mathrm{Er}, \mathrm{Tm})$ and $400{ }^{\circ} \mathrm{C}(\mathrm{Gd}$ to $\mathrm{Ho}$, $\mathrm{Yb}, \mathrm{Lu}, \mathrm{Y})$, showing that the anhydrous compounds are more stable in $\mathrm{CO}_{2}$ than in an air atmosphere. Above these temperatures the TG DTA curves show mass losses in steps characteristic of each compound and the general aspect of these curves allows the division into the four groups; first group: $\mathrm{La}, \mathrm{Pr}, \mathrm{Nd}$; second group: $\mathrm{Ce}, \mathrm{Sm}, \mathrm{Gd}, \mathrm{Tb}$; Third group: $\mathrm{Eu}$ and fourth group: Dy to Lu and Y. Thus the feature of each of these compounds are discussed on the base of their similar thermal profiles.
Lanthanum, praseodymium and neodymium compounds

The TG-DTA curves of the lanthanum and praseodymium as representative of these compounds are shown in Fig. 1. The first mass loss up to $130^{\circ} \mathrm{C}(\mathrm{La})$ and $120^{\circ} \mathrm{C}(\mathrm{Pr}, \mathrm{Nd})$ with the corresponding endothermic peaks at $120^{\circ} \mathrm{C}(\mathrm{La})$ and $110{ }^{\circ} \mathrm{C}(\mathrm{Pr}, \mathrm{Nd})$ is due to the release of $2.5 \mathrm{H}_{2} \mathrm{O}$ $(\mathrm{Nd})$ and $2 \mathrm{H}_{2} \mathrm{O}$ ( $\left.\mathrm{La}, \mathrm{Pr}\right)$.

After their dehydration the anhydrous compounds are stable up to $350{ }^{\circ} \mathrm{C}$, and the endothermic peaks at $250{ }^{\circ} \mathrm{C}(\mathrm{La}), 245^{\circ} \mathrm{C}(\mathrm{Pr})$ and $240{ }^{\circ} \mathrm{C}(\mathrm{Nd})$ are atributed to the reversible crystalline phase transition, in agreement with the thermal decomposition of these compounds in an air atmosphere [25].

The thermal decomposition of the anhydrous compounds occurs in three ( $\mathrm{La}, \mathrm{Pr}$ ) and four $(\mathrm{Nd})$ steps. The first one corresponding to endothermic peaks is attributed to thermal decomposition of these compounds and tests with hydrochloric acid solution on samples heated up to the final temperature of this step, showed in all

Table 1. Analytical and thermoanalytical (TG) data of the compounds.

\begin{tabular}{|c|c|c|c|c|c|c|c|c|c|c|c|c|}
\hline \multirow{2}{*}{ Compound } & \multicolumn{3}{|c|}{ Metal oxide (\%) } & \multicolumn{2}{|c|}{$\Delta(\mathrm{L})(\%)$} & \multicolumn{2}{|c|}{$\mathrm{H}_{2} \mathrm{O}(\%)$} & \multicolumn{2}{|c|}{$\mathrm{C}(\%)$} & \multicolumn{2}{|c|}{$\mathrm{H}(\%)$} & \multirow{2}{*}{ Final Residue } \\
\hline & Calcd. & TG & EDTA & Calcd. & TG & Calcd. & TG & Calcd. & $\mathrm{AE}$ & Calcd. & $\mathrm{AE}$ & \\
\hline $\mathrm{La}(\mathrm{Bz})_{3} .2 \mathrm{H}_{2} \mathrm{O}$ & 30,26 & 29,79 & 30,35 & 63,04 & 63,48 & 6,70 & 6,73 & 46.85 & 47.06 & 2.81 & 2.82 & $\mathrm{La}_{2} \mathrm{O}_{3}$ \\
\hline $\mathrm{Ce}(\mathrm{Bz})_{3} \cdot 2 \mathrm{H}_{2} \mathrm{O}$ & 31,90 & 32,00 & 31,76 & 61,42 & 61,30 & 6,68 & 6,70 & 46.75 & 46.69 & 2.81 & 2.80 & $\mathrm{CeO}_{2}$ \\
\hline $\operatorname{Pr}(\mathrm{Bz})_{3} .2 \mathrm{H}_{2} \mathrm{O}$ & 31,51 & 31,40 & 31,74 & 61,82 & 61,76 & 6,67 & 6,84 & 46.68 & 46.65 & 2.80 & 2.80 & $\mathrm{Pr}_{6} \mathrm{O}_{11}$ \\
\hline $\mathrm{Nd}(\mathrm{Bz})_{3} .2,5 \mathrm{H}_{2} \mathrm{O}$ & 30,44 & 30,55 & 30,03 & 61,41 & 61,55 & 8,15 & 7,90 & 45.64 & 45.70 & 2.74 & 2.73 & $\mathrm{Nd}_{2} \mathrm{O}_{3}$ \\
\hline $\mathrm{Sm}(\mathrm{Bz})_{3} .2 \mathrm{H}_{2} \mathrm{O}$ & 31,71 & 31,86 & 31,62 & 61,73 & 61,49 & 6,56 & 6,65 & 45.87 & 45.75 & 2.76 & 2.74 & $\mathrm{Sm}_{2} \mathrm{O}_{3}$ \\
\hline $\mathrm{Eu}(\mathrm{Bz})_{3} .1,5 \mathrm{H}_{2} \mathrm{O}$ & 32,45 & 32,35 & 32,21 & 62,57 & 62,50 & 4,98 & 5,15 & 46.50 & 46.47 & 2.79 & 2.81 & $\mathrm{Eu}_{2} \mathrm{O}_{3}$ \\
\hline $\mathrm{Gd}(\mathrm{Bz})_{3} .1,5 \mathrm{H}_{2} \mathrm{O}$ & 33,10 & 33,19 & 32,88 & 61,96 & 61,78 & 4,94 & 5,03 & 46.05 & 46.13 & 2.77 & 2.80 & $\mathrm{Gd}_{2} \mathrm{O}_{3}$ \\
\hline $\mathrm{Tb}(\mathrm{Bz})_{3} .1 \mathrm{H}_{2} \mathrm{O}$ & 34,60 & 34,46 & 34,60 & 62,06 & 62,14 & 3,34 & 3,40 & 46.65 & 46.69 & 2.80 & 2.81 & $\mathrm{~Tb}_{4} \mathrm{O}_{7}$ \\
\hline $\mathrm{Dy}(\mathrm{Bz})_{3} .0,5 \mathrm{H}_{2} \mathrm{O}$ & 34,87 & 35,00 & 34,55 & 63,45 & 63,28 & 1,68 & 1,72 & 47.15 & 47.07 & 2.83 & 2.80 & $\mathrm{Dy}_{2} \mathrm{O}_{3}$ \\
\hline $\mathrm{Ho}(\mathrm{Bz})_{3}$ & 35,76 & 35,82 & 35,57 & 64,24 & 64,18 & & & 47.74 & 47.71 & 2.87 & 2.85 & $\mathrm{Ho}_{2} \mathrm{O}_{3}$ \\
\hline $\operatorname{Er}(\mathrm{Bz})_{3}$ & 36,04 & 36,17 & 36,01 & 63,96 & 63,83 & & & 47.53 & 47.47 & 2.86 & 2.85 & $\mathrm{Er}_{2} \mathrm{O}_{3}$ \\
\hline $\operatorname{Tm}(B z)_{3}$ & 36,24 & 36,35 & 36,58 & 63,75 & 63,65 & & & 47.38 & 47.33 & 2.85 & 2.83 & $\mathrm{Tm}_{2} \mathrm{O}_{3}$ \\
\hline $\mathrm{Yb}(\mathrm{Bz})_{3}$ & 36,73 & 36,66 & 36,85 & 63,27 & 63,34 & & & 47.02 & 47.10 & 2.82 & 2.83 & $\mathrm{Yb}_{2} \mathrm{O}_{3}$ \\
\hline $\mathrm{Lu}(\mathrm{Bz})_{3}$ & 36,90 & 37,14 & 36,71 & 63,10 & 62,86 & & & 46.84 & 46.73 & 2.81 & 2.81 & $\mathrm{Lu}_{2} \mathrm{O}_{3}$ \\
\hline $\mathrm{Y}(\mathrm{Bz})_{3}$ & 24,97 & 25,01 & 24,90 & 75,03 & 74,99 & & & 55.76 & 55.78 & 3.35 & 3.34 & $\mathrm{Y}_{2} \mathrm{O}_{3}$ \\
\hline
\end{tabular}


Table 2. Temperature ranges $\theta$, mass losses $(\Delta \mathrm{m})$ and peak temperatures observed for each step of the TG-DTA curves of the compounds $\mathrm{Ln}(\mathrm{Bz})_{3} \cdot \mathrm{H}_{2} \mathrm{O}$, where $\mathrm{Ln}=$ lanthanides; $\mathrm{Bz}=$ benzoate.

\begin{tabular}{|c|c|c|c|c|c|c|}
\hline \multirow{2}{*}{\multicolumn{2}{|c|}{ Compound }} & \multicolumn{4}{|c|}{ Steps } & \multirow{3}{*}{$\begin{array}{c}\begin{array}{c}\text { Crystalline } \\
\text { transition }\end{array} \\
250\end{array}$} \\
\hline & & \multirow{2}{*}{$\frac{1^{a}}{40-130}$} & \multirow{2}{*}{$\frac{2^{\mathrm{a}}}{350-640}$} & \multirow{2}{*}{$\frac{3^{\mathrm{a}}}{640-760}$} & \multirow{2}{*}{$\frac{4^{a}}{940-965}$} & \\
\hline $\mathrm{La}(\mathrm{Bz})_{3} \cdot 2 \mathrm{H}_{2} \mathrm{O}$ & $\theta^{\circ} \mathrm{C}$ & & & & & \\
\hline & $\Delta \mathrm{m}(\%)$ & 6.60 & 51.43 & 7.05 & 4.02 & \\
\hline & Peak $\left({ }^{\circ} \mathrm{C}\right)$ & 120 & 610 & 700 & 955 & \\
\hline \multirow[t]{3}{*}{$\mathrm{Ce}(\mathrm{Bz})_{3} .2 \mathrm{H}_{2} \mathrm{O}$} & $\theta^{\circ} \mathrm{C}$ & $45-120$ & $350-625$ & $625-750$ & - & 250 \\
\hline & $\Delta \mathrm{m}(\%)$ & 6.94 & 50.84 & 10.62 & & \\
\hline & Peak $\left({ }^{\circ} \mathrm{C}\right)$ & 110 & 570 & 660 & & \\
\hline \multirow[t]{3}{*}{$\operatorname{Pr}(\mathrm{Bz})_{3} .2 \mathrm{H}_{2} \mathrm{O}$} & $\theta^{\circ} \mathrm{C}$ & $35-120$ & $350-610$ & $610-760$ & $845-900$ & 245 \\
\hline & $\Delta \mathrm{m}(\%)$ & 6.82 & 50.93 & 6.80 & 4.00 & \\
\hline & Peak $\left({ }^{\circ} \mathrm{C}\right)$ & 110 & 560 & 675 & 860 & \\
\hline \multirow[t]{3}{*}{$\mathrm{Nd}(\mathrm{Bz})_{3} .2,5 \mathrm{H}_{2} \mathrm{O}$} & $\theta^{0} \mathrm{C}$ & $40-120$ & $350-630$ & $630-840$ & $880-910$ & 240 \\
\hline & $\Delta \mathrm{m}(\%)$ & 7.85 & 50.35 & 7.06 & 4.00 & \\
\hline & Peak $\left({ }^{\circ} \mathrm{C}\right)$ & 110 & 500 & 555 & 890 & \\
\hline \multirow[t]{3}{*}{$\mathrm{Sm}(\mathrm{Bz})_{3} .2 \mathrm{H}_{2} \mathrm{O}$} & $\theta^{\circ} \mathrm{C}$ & $45-110$ & $350-630$ & $630-800$ & $530-680$ & 230 \\
\hline & $\Delta \mathrm{m}(\%)$ & 6.44 & 51.34 & 10.48 & - & \\
\hline & Peak $\left({ }^{\circ} \mathrm{C}\right)$ & 105 & 550 & 690 & - & \\
\hline \multirow[t]{3}{*}{$\mathrm{Eu}(\mathrm{Bz})_{3} \cdot 1,5 \mathrm{H}_{2} \mathrm{O}$} & $\theta^{\circ} \mathrm{C}$ & $35-110$ & $375-580$ & $580-850$ & - & 245 \\
\hline & $\Delta \mathrm{m}(\%)$ & 4.81 & 51.65 & 11.21 & - & \\
\hline & Peak $\left({ }^{\circ} \mathrm{C}\right)$ & 105 & 540 & 830 & - & \\
\hline \multirow[t]{3}{*}{$\mathrm{Gd}(\mathrm{Bz})_{3} .1,5 \mathrm{H}_{2} \mathrm{O}$} & $\theta^{\circ} \mathrm{C}$ & $40-105$ & $400-620$ & $620-820$ & - & 250 \\
\hline & $\Delta \mathrm{m}(\%)$ & 4.64 & 50.85 & 11.06 & & \\
\hline & Peak $\left({ }^{\circ} \mathrm{C}\right)$ & 100 & 550 & 760 & & \\
\hline \multirow[t]{3}{*}{$\mathrm{Tb}(\mathrm{Bz})_{3} .1 \mathrm{H}_{2} \mathrm{O}$} & $\theta^{\circ} \mathrm{C}$ & $40-95$ & $400-615$ & $615-910$ & & 265 \\
\hline & $\Delta \mathrm{m}(\%)$ & 3.26 & 51.21 & 11.20 & & \\
\hline & Peak $\left({ }^{\circ} \mathrm{C}\right)$ & 90 & 555 & 840 & & \\
\hline \multirow[t]{3}{*}{$\mathrm{Dy}(\mathrm{Bz})_{3}$} & $\theta^{\circ} \mathrm{C}$ & $400-620$ & $620-910$ & - & - & 270 \\
\hline & $\Delta \mathrm{m}(\%)$ & 55.44 & 8.74 & - & - & \\
\hline & Peak $\left({ }^{\circ} \mathrm{C}\right)$ & 560 & 680 & - & - & \\
\hline \multirow[t]{3}{*}{$\mathrm{Ho}(\mathrm{Bz})_{3}$} & $\theta^{\circ} \mathrm{C}$ & $400-620$ & $620-965$ & - & - & 280 \\
\hline & $\Delta \mathrm{m}(\%)$ & 54.49 & 10.05 & - & - & \\
\hline & Peak $\left({ }^{\circ} \mathrm{C}\right)$ & 565 & 690 & - & - & \\
\hline \multirow[t]{3}{*}{$\operatorname{Er}(\mathrm{Bz})_{3}$} & $\theta^{\circ} \mathrm{C}$ & $385-625$ & $625-970$ & - & - & 280 \\
\hline & $\Delta \mathrm{m}(\%)$ & 55.39 & 8.41 & - & - & \\
\hline & Peak $\left({ }^{\circ} \mathrm{C}\right)$ & 580 & 700 & - & - & \\
\hline \multirow[t]{3}{*}{$\operatorname{Tm}(B z)_{3}$} & $\theta^{\circ} \mathrm{C}$ & $385-625$ & $625-1040$ & - & - & 280 \\
\hline & $\Delta \mathrm{m}(\%)$ & 56.35 & 7.51 & - & - & \\
\hline & Peak $\left({ }^{\circ} \mathrm{C}\right)$ & 580 & 690 & - & - & \\
\hline \multirow[t]{3}{*}{$\mathrm{Yb}(\mathrm{Bz})_{3}$} & $\theta^{\circ} \mathrm{C}$ & $400-630$ & $630-1010$ & - & - & 280 \\
\hline & $\Delta \mathrm{m}(\%)$ & 53.84 & 9.54 & - & - & \\
\hline & Peak $\left({ }^{\circ} \mathrm{C}\right)$ & 580 & 710 & - & - & \\
\hline \multirow[t]{3}{*}{$\mathrm{Lu}(\mathrm{Bz})_{3}$} & $\theta^{\circ} \mathrm{C}$ & $400-630$ & $630-1020$ & - & - & 275 \\
\hline & $\Delta \mathrm{m}(\%)$ & 54.77 & 8.09 & - & - & \\
\hline & Peak $\left({ }^{\circ} \mathrm{C}\right)$ & 610 & 700 & - & - & \\
\hline \multirow[t]{3}{*}{$\mathrm{Y}(\mathrm{Bz})_{3}$} & $\theta^{\circ} \mathrm{C}$ & $400-620$ & $620-990$ & - & - & 280 \\
\hline & $\Delta \mathrm{m}(\%)$ & 62.37 & 12.75 & - & - & \\
\hline & Peak $\left({ }^{\circ} \mathrm{C}\right)$ & 590 & 720,800 & - & - & \\
\hline
\end{tabular}

cases, the presence of carbonaceous residue and evolution of $\mathrm{CO}_{2}$, indicating the formation of carbonate or a derivative of carbonate, as intermedi- ate. The formation of carbonate or derivative carbonate and carbonaceous residue, undoubtedly was favoured by $\mathrm{CO}_{2}$ used as purge gas. The for- 
mation of intermediate derivative of carbonate had already been observed during the thermal decomposition of other lanthanide compounds [26, 27].

The second step corresponding to endothermic peaks is attributed to the thermal decomposition of the intermediate and carbonaceous residue to lanthanide dioxycarbonate [26, 27]. The last (La, $\mathrm{Pr})$ or the two last $(\mathrm{Nd})$ steps corresponding to endothermic peaks are attributed to the thermal decomposition of the dioxycarbonate to the respective oxide, $\mathrm{La}_{2} \mathrm{O}_{3}, \mathrm{Pr}_{6} \mathrm{O}_{11}, \mathrm{Nd}_{2} \mathrm{O}_{3}$.

\section{Cerium, samarium, gadolinium and terbium com- pounds}

The TG-DTA curves of the cerium and gadolinium as representative of these compounds are shown in Fig. 1. The first mass loss up to 120 ${ }^{\circ} \mathrm{C}(\mathrm{Ce}), 110{ }^{\circ} \mathrm{C}(\mathrm{Sm}), 105^{\circ} \mathrm{C}(\mathrm{Gd})$ and $95^{\circ} \mathrm{C}(\mathrm{Tb})$ with the corresponding endothermic peak at 115 ${ }^{\circ} \mathrm{C}(\mathrm{Ce}), 105^{\circ} \mathrm{C}(\mathrm{Sm}), 100{ }^{\circ} \mathrm{C}(\mathrm{Gd})$ and $90{ }^{\circ} \mathrm{C}(\mathrm{Tb})$ is due to the dehydration with loss of $2 \mathrm{H}_{2} \mathrm{O}(\mathrm{Ce}$, $\mathrm{Sm}), 1.5 \mathrm{H}_{2} \mathrm{O}(\mathrm{Gd})$ and $1 \mathrm{H}_{2} \mathrm{O}(\mathrm{Tb})$.

The anhydrous compounds are stable up to $350{ }^{\circ} \mathrm{C}(\mathrm{Ce}, \mathrm{Sm})$ and $400{ }^{\circ} \mathrm{C}(\mathrm{Gd}, \mathrm{Tb})$ and the endothermic peak at $250^{\circ} \mathrm{C}(\mathrm{Ce}, \mathrm{Gd}), 230^{\circ} \mathrm{C}(\mathrm{Sm})$ and $265^{\circ} \mathrm{C}(\mathrm{Tb})$ is ascribed to the reversible crystalline phase transition, as already observed [25].

The thermal decomposition of the anhydrous compounds takes place in two steps. The first one accompanied by a small endothermic peak is attributed to the thermal decomposition of these compounds with the formation of a mixture of carbonaceous residue and carbonate or a derivative of carbonate, as intermediate.

The last mass loss corresponding to the endothermic peaks is attributed to the thermal decomposition of the carbonaceous residue and of the intermediate to the respective oxide; $\mathrm{CeO}_{2}$, $\mathrm{Sm}_{2} \mathrm{O}_{3}, \mathrm{Gd}_{2} \mathrm{O}_{3}$ and $\mathrm{Tb}_{4} \mathrm{O}_{7}$.

\section{Europium compound}

The TG-DTA curves of the europium compound are shown in Fig. 1. The first mass loss up to $110{ }^{\circ} \mathrm{C}$ with the corresponding endothermic peak at $105{ }^{\circ} \mathrm{C}$ is due to the dehydration with loss of $1.5 \mathrm{H}_{2} \mathrm{O}$.

The anhydrous compound is stable up to 375 ${ }^{\circ} \mathrm{C}$ and the endothermic peak at $245^{\circ} \mathrm{C}$ is attributed to the reversible crystalline phase transition [25].
The thermal decomposition of the anhydrous compounds takes place in three steps with the two last overlapping ones. The first step corresponding to endothermic peak is attributed to the thermal decomposition of the compound with the formation of a mixture of carbonaceous residue and a derivative of carbonate, as intermediate.

The two last overlapping mass losses corresponding to the endothermic peaks are attributed to the thermal decomposition of the carbonaceous residue and of the intermediate to the respective oxide, $\mathrm{Eu}_{2} \mathrm{O}_{3}$.

\section{Dysprosium to lutetium and yttrium compounds}

The TG-DTA curves of the holmium and ytterbium as representative of these compounds are shown in Fig. 1. these curves show that all the compounds were obtained in the anhydrous state and stable up to $385{ }^{\circ} \mathrm{C}(\mathrm{Eu}, \mathrm{Tm}) 400{ }^{\circ} \mathrm{C}$ (Dy, Ho, Yb, Lu) and $420{ }^{\circ} \mathrm{C}(\mathrm{Y})$ and the endothermic peak at $270{ }^{\circ} \mathrm{C}$ (Dy), $275^{\circ} \mathrm{C}(\mathrm{Lu})$ and $280{ }^{\circ} \mathrm{C}$ (Ho, to $\mathrm{Yb}, \mathrm{Y}$ ) is ascribed to the reversible crystalline phase transition [25].

The thermal decomposition of these compounds occurs in three (Ho to $\mathrm{Lu}$ ) or four (Dy, Y) steps. The first one corresponding to endothermic peaks is attributed to the thermal decomposition of these compounds with the formation of an intermediate derivative of carbonate and carbonaceous residue. Above $620{ }^{\circ} \mathrm{C}$ (Dy to $\mathrm{Yb})$ and $630{ }^{\circ} \mathrm{C}(\mathrm{Lu}, \mathrm{Y})$ the mass losses corresponding to endothermic peaks are attributed to the thermal decomposition of the intermediate derivative of carbonate followed by the carbonaceous residue, with formation of the respective oxide, $\mathrm{Ln}_{2} \mathrm{O}_{3}(\mathrm{Ln}=$ Dy to $\mathrm{Lu}, \mathrm{Y})$. For these compounds the thermal decomposition of the intermediate derivative of carbonate occurs before of the carbonaceous residue, due to the decreasing thermal stability of these intermediates with increasing atomic number of the lanthanide ions, as had already been observed [28]. For this reason the large endothermic event between 850 $1100{ }^{\circ} \mathrm{C}$ attributed to the thermal decomposition of the carbonaceous residue is not observed for the light lanthanide compounds since the carbonaceous residue is evolved before the thermal decomposition of the intermediate derivative of the carbonate. 


\section{Conclusions}

In the dehydration process of these compounds, no influence of the atmosphere $\left(\mathrm{CO}_{2}\right.$ or air) is observed in TG-DTA curves, however the thermal decomposition of the anhydrous compounds significative differences is observed.

The thermal decomposition in air atmosphere, the TG-DTA curves suggest the formation of dioxycarbonate or a mixture of dioxycarbonate and oxide only for $\mathrm{La}, \mathrm{Nd}, \mathrm{Sm}$ and $\mathrm{Eu}$ compounds, while in a $\mathrm{CO}_{2}$ atmosphere the TG-DTA curves suggest for all the compounds the formation of a mixture of carbonate, oxy or dioxycar- bonate, as intermediate.

These curves also show that the thermal stability of the anhydrous compounds is greater in $\mathrm{CO}_{2}$ than in an air atmosphere.

\section{Acknowledgements}

The authors thank FAPESP, CNPq and CAPES Foundations (Brazil) for financial support.

Recebido em 30 de janeiro de 2008 Aceito em 04 de março de 2008.

J. R. Locatelli, A. B. Siqueira, C. T. Carvalho, M. Ionashiro. Decomposição térmica dos benzoatos de lantanídeos e ítrio no estado sólido em atmosfera de $\mathrm{CO}_{2}$.

Resumo: Foram sintetizados no estado sólido os compostos Ln-Bz, onde Ln representa lantanídeos trivalentes e Bz benzoato. Análise termogravimétrica e análise térmica diferencial (TG/DTA) foi usada para estudar a decomposição térmica destes compostos em atmosfera de $\mathrm{CO}_{2}$.

Palavras chaves: lantanídeos, benzoato, decomposição térmica, atmosfera de $\mathrm{CO}_{2}$.

\section{References}

[1]. S. J. Yun, S. K. Kang, S. S.Yun. Thermochim. Acta, 331 (1999) 13.

[2] Z. M. Wang, L. J. Van de Burgt, G. R. Choppin. Inorg. Chim. Acta 293 (1999) 167.

[3]. N.Arnaud, J. Georges. Analyst, 125 (2000) 1487.

[4]. G. R. Choppin, P. A. Bertrand, Y. Hasegawa, N. Rizalla. Inorg. Chem. 21(10) (1982) 3722.

[5]. Alex Wai-Hing Lam, Wing-Tak Wong, Song Gao, Gehui Wen, Xi-Xiang Zhang. Eu. J. Inorg. Chem. (1) (2003) 149.

[6]. W. W. Wendlandt. Anal. Chem. 17 (1957) 295.

[7]. S. B. Pirkes, G. N. Makushova, A. V. Lapitskaya Russian J. Inorg. Chem. 661 (1976) 21.

[8]. S. B. Pirkes, A. V. Lapitskaya, G. N. Makushova. Russian J. Inorg. Chem. 21 (1976) 816.

[9]. G. N. Makushova, A. V. Lapitskaya, S. O. Goppe, S. B. Pirkes. Russian J. Inorg. Chem. 24 (1979) 1574.

[10]. S. B. Pirkes, G. N. Makushova, A. V. Lapitskaya, N. P. Tsilina. Russian J. Inorg. Chem. 28 (1983) 1684.

[11]. W. Lewandowski. J. Molec. Strut. 101(1-2) (1983) 93.

[12]. G. N. Makushova, S. B. Pirkes. Russian J. Inorg. Chem. 29 (1984) 531.

[13]. G. N. Makushova, S. B. Pirkes, E. Yu. Levina. Russian J. Inorg. Chem. 30 (1985) 652.

[14]. W. Lewandowski, H. Baranska. J. Raman Spectroscopy. 17 (1986) 17.

[15]. G. N. Makushova, S. B. Pirkes, Russian J. Inorg. Chem. 32 (1987) 489.
[16]. W. Ferenc, B. Bocian, J. Thermal Anal. Cal. 62 (2000) 831.

[17]. B. Bocian, B. Czajka, W. Ferenc, J. Thermal Anal. Cal. 66 (2001) 729.

[18]. B. Czajka, B. Bocian, W. Ferenc. J. Thermal Anal. Cal. 67 (2002) 631.

[19]. W. Ferenc, B. Bocian. J. Thermal Anal. Cal. 74 (2003) 521.

[20]. W. Ferenc, A. Walkow-Dziewulska, J. Thermal Anal. Cal. 71 (2003) 375.

[21]. W. Ferenc, B. Bocian, A. Walków-Dziewulska. J. Thermal Anal. Cal. 76 (2004) 179.

[22]. E. C. Rodrigues, A. B. Siqueira, E. Y. Ionashiro, G. Bannach, M. Ionashiro. Ecl. Quim. 31(1) (2006) 21.

[23]. E. C. Rodrigues, A. B. Siqueira, E. Y. Ionashiro, G. Bannach, M. Ionashiro. Thermochim. Acta, 451 (2006) 149.

[24]. A. B. Siqueira, E. Y. Ionashiro, C. T. De Carvalho, G. Bannach, E. C. Rodrigues, M. Ionashiro. Quim. Nova, 30(2) (2007)318.

[25]. J. R. Locatelli, E. C. Rodrigues, A. B. Siqueira, E. Y. Ionashiro, G. Bannach, M. Ionashiro J. Thermal Anal. Cal., 90(3) (2007) 737.

[26]. L. C. S. de Oliveira, C. B. Melios, M. Spirandeli Crespi, C. A. Ribeiro, M. Ionashiro, Thermochim Acta, 219 (1993) 215.

[27]. M. H. Miyano, C. B. Melios, C. A. Ribeiro, H. Redigo, M. Ionashiro, Thermochim. Acta, 221 (1993)53.

[28]. L. Moscardini D' Assunção, I. Giolito, M. Ionashiro, Thermohim. Acta, 137 (1989) 319. 